\title{
The Role of Family Hope Program Actor in Empowering Poor Society (Case Study of Bone Regency) Indonesia
}

\author{
Misnawati Misnawati (Correspondence Author) \\ Regional Development Planning Study Program, Graduate School Hasanuddin \\ University, Makassar, Indonesia
}

Hasbi

Departemen Sosiologi, Fakultas Ilmu Sosial dan Ilmu Politik, Universitas Hasanuddin,

Makassar, Indonesia

Abd Rasyid J

Hasanuddin University, Makassar, Indonesia

Yusriadi Yusriadi

Sekolah Tinggi Ilmu Hukum Pengayoman, Makassar, Indonesia

Saidna Zulfiqar Bin-Tahir

University of Iqra Buru, Maluku, Indonesia

Received: June 3, 2019 Accepted: June 20, 2019 Online published: July 3, 2019

doi:10.5296/jpag.v9i2.14875 URL: https://doi.org/10.5296/jpag.v9i2.14875

\begin{abstract}
The Family Hope Program (PKH) is one of government policy programs in poverty alleviation by involving the main actor who called PPKH. This study aimed to describe the task and function of PPKH in empowering the sick society in Bone Regency. Qualitative approach used with case study research. Data collection techniques used was interviews, observation, and documentation. The instrument in this study was the researcher himself as a
\end{abstract}


human instrument, while the informants selected by a purposive method. Data analysis techniques used an interactive model includes data collection, data reduction, data presentation, verification, and conclusion. The results of the study showed that PPKH has carried out their roles well as representatives and technicians but have not been optimal in their roles as facilitators and educators.

Keywords: family hope program, government policy, poverty, poverty alleviation

\section{Introduction}

Poverty occurs in various parts of the world, even for centuries, even from the time of the Prophets. As because of alms or zakat where those are poor get a portion of their own to improve people's lives. Likewise, in the current reform era, groups of people who are below the poverty line must get special attention from all relevant parties.

The National Statistics Agency of March 2018 noted that the number of Indonesians poverty (residents with expenditure per capita of per month below the poverty line) reached 25.95 million people (9.82 percent). 1.82 million people reduced this number compared to the conditions in March 2017, which amounted to 27.77 million people (10.64 percent). While the poverty data of South Sulawesi Province is ranked 18th out of 34 provinces, it has also decreased from the March 2017 condition of 813.07 thousand to 792.63 thousand of March 2018.

This reduction does not take by a little way, but with various social protection efforts carried out by the government. This protection is an essential means to reduce the impact of poverty, although it is not the only approach in poverty alleviation if combined with social services, education, and integrated health it will be able to encourage accelerated development and economic growth (Ludoni, S, Noor \& Hakim, 2016). Therefore, it is necessary to develop a policy in the field of social protection by integrating indicators of achievement in education, health, and social welfare to accelerate the performance of the goals of the SDGs by focusing on the implementation of all the community through the Family Hope Program (PKH).

PKH was launched in 2007 by Susilo Bambang Yudhoyono were in other countries known as Conditional Cash Transfers (CCT). PKH was carried out by the Family Hope Program Actor (PPKH) with a total of 39,566 people throughout Indonesia. Initially implemented, PKH only touched seven provinces, 48 districts and served 387,928 recipient families who become the pilot areas for implementing the program. In 2010, the implementation of PKH developed into 25 Provinces, 118 Districts, and 1.1 million recipients including South Sulawesi and by all Regencies including Bone with $121 \mathrm{PPKH}$, consisting of 2 Coordinators, 2 Supervisors, 8 Database Administrators, and 109 Social Facilitators.

PKH in Bone Regency has been running for eight years, but its poverty rate continues to increase from year to year, as many 75,010 people in 2015, up to 75,090 people in 2016, and 77,130 people in 2017 and 2018. This data explains that the poor in Bone Regency is still very high and have been no significant changes during the implementation of PKH even though on a national scale, Indonesia has succeeded in reducing the single digit poverty rate from 10.64 percent to 9.82 percent. 
With this condition, the authors are interested in research to find out and describe the role of PPKH in empowering the poor as poverty alleviation. Another reason for selecting PPKH of Bone Regency was the largest area in South Sulawesi with the population in mid-2018 as much as 754,894 citizens with the field of 4,559 $\mathrm{km}^{2}$ (Statistics of Bone Regency, 2018). Therefore, the success or failure of this program will be an illustration of the success or failure of PPKH up to the national scale so that the authors feel it is crucial to research whether PPKH in Bone District has carried out its role well or not.

\section{Method}

This study used a qualitative approach with case study research. The goal is to obtain data comprehensive or holistic and in-depth (Judistira \& Garna, 2008). They are intended to describe informants experiences related to poverty alleviation policies as PPKH. The instrument in this study was the researcher himself (human instrument) who have prepared themselves by deepening qualitative methods, mastering the theories related to poverty alleviation that have been studied, and giving meaning to all the results of this research, which utilized for all PKH organizers. The primary data sources in this study were through interviews with eight informants who were directly involved in PKH in Bone Regency. While additional data sources obtained from observations where researchers observe the places and events and activities of PKH actors in carrying out their duties directly, and documentation originating from relevant laws and regulations, $\mathrm{PKH}$ data, and various other data that can use as material for analysis. Those participants selected through purposive sampling technique and for triangulation purposes, the data were also obtained by source, method, and time. The study used the approach analyzes an interactive model (Miles, Huberman, \& Saldana, 2014) that consisted of three essential components, namely; 1) data reduction from editing, coding, to data tabulation; 2) data presentation through assembling information that allows completion of research data so that researchers easily understand what happened and what done, and 3) conclusion or verification. The mechanism took place interactively back and forth depending on the complexity of the problem that the researcher wants to answer. The analysis started from the data collection and continued until the time the research ended.

\section{Results and Discussion}

Bone Regency began to get social assistance from PKH in 2010. Throughout 2010 until now $\mathrm{PKH}$ Bone has received several extensions both to the actors and to the recipients of the program. The Indonesian government, through $\mathrm{PKH}$, has provided immense opportunities for young people to hone their abilities and qualities, especially as an extension of the government in prospering communities throughout Indonesia. Through PKH, the youth gave the task and responsibility in providing assistance and empowerment of the poor towards prosperity who called Family Hope Program Actor (PPKH). PPKH Bone Regency divided into two parts of coordination which are coordinated respectively by the Supervisor and Coordinator called Region I and Region II in guarding 33,367 Beneficiary Families. PPKH has a position as a partner of the government and community who required to be the pioneers of social functioning in bridging all government and community social interests. The roles of PPKH based on the concept of community worker were facilitative, educative, representative, 
and technical (Habibullah, 2011).

The facilitative role aims to provide encouragement or uplift the target group or client so that they can create changes in their environmental conditions. In this role, PPKH has duties and responsibilities as social animators in providing stimuli, and motivation to KPM, mediators, and negotiators in helping KPM needs and rights and resolving internal or external conflicts occur in groups.

PPKH as a facilitator must have high enthusiasm so that the activities that have planned with the KPM can be carried out. PPKH Bone Regency always strives to be an excellent facilitator by providing stimulation, encouragement, and motivation to fulfill obligations as PKH participation requirement. One of KPM obligations is to participate in school attendance and health facilities and also to attend monthly group meetings held by PPKH. Besides that, PPKH Bone Regency also acts as a good mediator and negotiator by being the first source of complaints of all problems kinds faced by KPM. Claims can form as requests for the fulfillment of other complementary social assistance or conflicts and difficulties faced by KPM. PPKH directs itself to be a mediator in a middle and neutral position between the dispute parties and to find agreements so achieving results that satisfy the dispute parties (Abbas, 2011).

While the role of PPKH in Bone Regency as a group and organizing facilitator has not run well and optimally, organizing carried out by facilitators is only limited to group formation as a regular meeting place. The group is not prepared and empowered for business establishment activities, whether for group business or individuals. There has not been an effort from PPKH to manage the potential exists in the assisted area so that it can be a trigger to increase the living standard of KPM to not depend on PKH when the program ends.

The educative role is the active involvement role of social workers in the process of implementing all planned activities together with the target group according to their needs. PPKH intended as an agent that provides positive input and directives based on their knowledge and experience in raising public awareness, delivering information, and conducting training for the community. Revealed that the purpose of social work is to increase the ability of humans in solving problems, facing difficulties, and carrying out their life's tasks effectively (Damanik, 2008).

In this program, one form of effort in increasing awareness and changing people's thinking patterns, PPKH is required to carry out regular group meetings every month with the assisted KPM. In this meeting, PPKH was given free space to provide positive education to KPM such as Family Development Session. The foundation of the task and role of PPKH is to consciously and planned to realize the learning atmosphere and the learning process for the assisted poor actively to develop their potential (Sastrohadiwiryo, 2013) so that the active learning process for KPM carried out actively and routinely.

Based on the results of the study, PPKH Bone Regency has tried to provide an excellent education to KPM especially in raising awareness and changing their thinking patterns about the importance of education and health in improving the quality of family life in the future. 
PPKH here is as an educator who conveys educational content regarding child education and care, the economy, health and protection of children, the elderly, and disability. However, the learning process that has been carried out has not run optimally because it has not been routinely implemented, learning that should be carried out every month but only carried out every three months. PPKH has other activities outside its obligations, such as continuing their education so that it cannot carry out the monthly learning process to the assisted community. Even though according to technical program instructions, a meeting must take every month. In this connection, the demand that must fulfill is a commitment to realize an active and routine learning process. So that KPM can develop themselves so that it has the power to create better patterns of thinking and behavior patterns. One of the methods in developing the capacity is education and training activities (Yusriadi, Sahid, Amirullah, Azis, \& Rachman, 2019).

Representative is the role that attached to social workers in acting as representatives of society. Social workers act as enablers or as agents of change who play a role in representing or assisting all the interests and needs of the supported community. This role means representing the oppressed and marginalized interests of KPM so that their rights can be fulfilled such as arguing, lobbying with power holders, forming representatives, and defending KPM. By the objectives of social work, it is "connecting people with systems that can provide the source of services and opportunities needed, and improve the ability to implement the system effectively and humanely" (Hermawati, 2001).

PPKH in carrying out its role as a representative for KPM can conduct visits to health services such as Community Health centers also educational services where PKH participants' children attend school. A companion assignment as a community representative which was carried out for the quality of services obtained by PKH participants. Service quality is the level of service provided by PPKH to meet KPM expectations where it can know by comparing the customer's perceptions of what expected and felt. If services are perceived to be by the anticipated services, then the quality of these services will be regarded as ethical or positive. If services are seen to exceed services expected, then the quality of services is perceived as ideal quality. Likewise, if services recognized as worse than expected services, the quality of services is seen as negative or harmful. So whether good or not the quality of service depends on PPKH's ability to meet KPM's expectations consistently.

PPKH Bone Regency as an advocator for KPM has been running well; it can be seen from there no entry fee for KPM children to continue their studies in vocational or high school. Also seen from the affairs carried out in the village by KPM who used to get difficulties in asking something in the village office, has been going well and smoothly after being facilitated by PPKH.

The technical role refers to the application of practical skills; the companion is required not only to be a "change manager" who organizes groups but is also able to perform technical tasks following various necessary skills. It is undeniable that today computers cannot make distinct from everyday life. The ability to use computers is crucial to support multiple activities such as PPKH not only must be able to be practical in the field but also must be 
experts in using computers. Based on the results of the study, PPKH Bone has performed an excellent technical skill role, namely providing material for KPM through the use of computers and it seems that almost PPKH members in presenting the content had used machines. Through socialization campaigns, carried through direct and indirect means that way, all prospective users of public services will have equal opportunity to have access to services they need, reducing possibilities of nepotism, bribery, and discrimination (Yusriadi, 2018a).

On the other hand, PPKH must be able to express their thoughts, actions both directly and in writing. This ability is an attraction to get KPM attention when the presentation process occurs. PPKH must be able to make the classroom learning process effective and quality. Such class conditions are expected to be able to improve KPM's skills and learning outcomes. With the right learning conditions, KPM will be increasingly motivated always to develop the abilities it has. The results of the study illustrate that PPKH Bone has provided excellent and pleasant teaching through several learning variations. The variation in these activities can overcome KPM saturation in the classroom. For example, in the beginning, PPKH was learning the story about something that could motivate KPM. Is good because later KPM participants will be enthusiastic during their learning activities, for example, every 15 minutes after explaining PPKH provides other fun activities such as games, singing, or another ice breaking. Another thing that makes connecting and engaging learning is the use of the regional language by PPKH to KPM so that KPM feels free and does not hesitate to talk because the companion knows how to chat with them. This principle shows that there is a concern for others; the program that is carried out based on the principle of cooperation (Umar et al., 2019).

Besides that, the use of learning tools can also help PPKH in creating a dynamic and fresh atmosphere, namely technology, such as laptops. With excellent and exciting presentation, KPM will be more focused on the subject matter delivered by PPKH. The development of e-government applications requires substantial funding, so readiness from the human resources side of the government apparatus is needed and preparedness from the community (Yusriadi, 2018b).

\section{Conclusion}

The Role of Family Hope Program Actor in empowering sick society has done through observation, interviews, and documentation. The authors conclude that the companion role divided into four of them are: 1) Facilitative role, that the PPKH has carried out his role as a social animator, mediator, and competent negotiator. They can provide stimulation and motivation to KPM, and helping to fill KPM needs and resolving the internal and external conflicts occur at KPM whereas, for being a facilitator and group organizer, PPKH has not done their role well and optimal. 2) The educative role that PPKH has fulfilled his role as an educator in raising KPM awareness and providing information and training through P2K2 or FDS. 3) The representative role that PPKH have carried out their task as representatives of the community by advocating for external services such as health facilities, educational facilities, and village government for the benefit of PKH participants. 4) KPM can understand 
the technical role, that PPKH have fulfilled the role of technical skills well through the ability in operating the computer and presenting the material verbally and in writing with audio and visual that effectively.

Based on the conclusions above, the researchers recommended some suggestions as evaluation materials and input for the development of PKH program, especially in Bone Regency. The government should optimize the performance of PPKH in the field, increase the quota of assisted communities, and divide tasks the actors adjusted to the domicile distance to create a more effective mentoring process. PPKH Bone regency must promote the socialization of the PKH process business to other parties to get community support in guarding and controlling $\mathrm{PKH}$ to be on target, and it is necessary to evaluate the accompanying performance so that it can alleviate social security by the objectives of the PKH program

\section{Reference}

Abbas, S. (2011). Mediasi Dalam Perspektif Hukum Syariah, Hukum Adat dan Hukum Nasional. Jakarta: Kencana.

Damanik, J. (2008). Pekerjaan sosial. Jakarta: Direktorat Pembinaan Sekolah Menengah Kejuruan, Direktorat Jenderal Manajemen Pendidikan Dasar dan Menengah Departemen Pendidikan Nasional.

Habibullah. (2011). Peran Pendamping Pada Program Keluarga Harapan Kabupaten Karawang. Jurnal Informasi (Kajian Permasalahan Sosial Dan Usaha Kesejahteraan Sosial), $16,101-116$.

Hermawati, I. (2001). Metode dan teknik dalam praktek pekerjaan sosial. Yogyakarta: Adicita Karya Nusa.

Judistira, K., \& Garna. (2008). Dasar dan Proses Penelitian Sosial. Bandung: Primaco Akademika.

Ludoni, S, Noor, I., \& Hakim, L. (2016). Perencanaan Program-Program Pengentasan Kemiskinan dalam Pencapaian Target MDGS Tahun 2015 di Kota Batu. Reformasi, 6.

Miles, M., Huberman, A., \& Saldana, J. (2014). Qualitative Data Analysis, A Methods Sourcebook (3rd ed.). USA: Sage Publications.

Sastrohadiwiryo, S. (2013). Pengantar Manajemen (9th ed.). Retrieved from https://bumiaksaraonline.com/pengantar-manajemen.html

Umar, A., Amrin, M. M., Farida, U., Yusriadi, T. H., ... Misnawati. (2019). One-Stop Service Policy as A Bureaucratic Reform in Indonesia. Academy of Strategic Management Journal, $18(2)$,
$1-12$.
Retrieved
from

https://www.abacademies.org/articles/onestop-service-policy-as-a-bureaucratic-reform-in-ind onesia-8027.html

Yusriadi. (2018a). Bureaucratic Reform Barriers: A Case Study on the One Stop-Integrated 


\section{Macrothink}

Journal of Public Administration and Governance

ISSN 2161-7104 2019, Vol. 9, No. 2

Service Office in Bone Regency. Jurnal Kebijakan Dan Administrasi Publik, 22(2), 146-154. Retrieved from https://jurnal.ugm.ac.id/jkap/article/view/34536

Yusriadi. (2018b). Reformasi Birokrasi Indonesia: Peluang dan Hambatan. Jurnal Administrasi Publik (Public Administration Journal), 8(2), 178-185. https://doi.org/10.31289/jap.v8i2.1824

Yusriadi, S. A., Amirullah, I., Azis, A., \& Rachman, A. A. (2019). Bureaucratic Reform to the Human Resouces: A Case Study on the One-Stop Integrated Service. The Journal of Social Sciences Research. https://doi.org/10.32861/jssr.51.61.66

\section{Copyright Disclaimer}

Copyright for this article is retained by the author(s), with first publication rights granted to the journal.

This is an open-access article distributed under the terms and conditions of the Creative Commons Attribution license (http://creativecommons.org/licenses/by/4.0/). 